\title{
PAUL RUDOLPH'S DESIGN PRINCIPLES ON HIGH-RISE OFFICE BUILDINGS IN INDONESIA CASE STUDY: WISMA DHARMALA SAKTI JAKARTA AND WISMA DHARMALA SAKTI SURABAYA
}

\author{
${ }^{1}$ Nabila Qirala Sukada. ${ }^{2}$ Dr. Ir. Purnama Salura, M.M, M.T. \\ ${ }^{1}$ Student in the Bachelor's (S-1) Study Program in Architecture \\ at Parahyangan Catholic University \\ ${ }^{2}$ Senior lecturer in the Bachelor's (S-1) Study Program in Architecture \\ at Parahyangan Catholic University
}

\begin{abstract}
Many of high-rise office buildings in Indonesia applies efficiency and effectivity of building form, cost, and time for construction as a number one priority. As a result, high-rise office buildings appears with a minimumarticulated form, and show the dominance by using glass materials as a facade. However, there are also high-rise office buildings that have an articulated form and its facades that are not dominated by glass, although they appear in small numbers. Wisma Dharmala Sakti Jakarta and Wisma Dharmala Sakti Surabaya are one of them. Moreover, both buildings were designed by foreign architect, Paul Rudolph. Based on the potentials of both buildings, this research focused on Paul Rudolph's principles in designing high-rise office buildings in Wisma Dharmala Sakti Jakarta and Wisma Dharmala Sakti Surabaya

Looking at the phenomena of high-rise office buildings in Indonesia as described earlier, this small number and the articulated form of high-rise office buildings designed by Paul Rudolph in Indonesia are interesting to be understood even more. The main purpose of this research is to reveal the relationship between Paul Rudolph's design principles with buildings, which are Wisma Dharmala Sakti Jakarta and Wisma Dharmala Sakti Surabaya.

Using an interpretative method in a qualitative research, this research utilized theories that helps understanding of an office building, theories that related to Paul Rudolph's background and common thought about architecture, and also Paul Rudolph's theory about determinants of architectural form as a literature study. Building's Anatomy Theory is used as a surgical tool to disect the study cases, which happens to be Wisma Dharmala Sakti Jakarta and Wisma Dharmala Sakti Surabaya.

Result of this research are six points of Paul Rudolph's principles in designing high-rise office building which are: repetition, space, scale, rotation, light, and context. Implementation of Paul Rudolph's design principles in both study cases can be seen in the dominance of rotation and repetition of building elements. The application of these two principles can fulfill all the three aspects of Paul Rudolph's design ideal, which are form, context, and cycle.

Benefit of this research is to enrich architectural vocabulary about design principles of a high-rise office buildings in Indonesia for the concerned educational institution, as a consideration and input to architects and the stakeholders to be more sensitive and critical in designing high-rise buildings in Indonesia, as a reference and study case about design principles of a high-rise office buildings for students, academics, architects, and the public with the focus of study concerned, and enrich the knowledge about Paul Rudolph's design principles especially in designing high-rise office buildings in Indonesia for researcher.
\end{abstract}

Keywords: Paul Rudolph, Design Principles, Office, Wisma Dharmala Sakti Jakarta, Wisma Dharmala Sakti Surabaya.

\section{PRINSIP PERANCANGAN PAUL RUDOLPH PADA BANGUNAN PERKANTORAN BERTINGKAT TINGGI DI INDONESIA}

\footnotetext{
${ }^{1}$ Corresponding Author: nabila.qirala@hotmail.com
} 


\title{
KASUS STUDI: WISMA DHARMALA SAKTI JAKARTA DAN WISMA DHARMALA SAKTI SURABAYA
}

\author{
${ }^{1}$ Nabila Qirala Sukada. ${ }^{2}$ Dr. Ir. Purnama Salura, M.M, M.T. \\ ${ }^{1}$ Mahasiswa S1 Program Studi Arsitektur Universitas Katolik Parahyangan. \\ 2 Dosen Pembimbing S1 Program Studi Arsitektur Universitas Katolik Parahyangan
}

\begin{abstract}
Abstrak- Mayoritas bangunan perkantoran bertingkat tinggi di Indonesia mengutamakan efisiensi dan efektifitas baik dari segi ruang, waktu, dan biaya pembangunan. Akibatnya muncul bentuk-bentuk bangunan perkantoran bertingkat tinggi yang minim artikulasi bentuk dan fasadnya yang di dominasi kaca telanjang. Walaupun demikian, terdapat pula bangunan perkantoran bertingkat tinggi yang memiliki artikulasi bentuk serta fasad yang tidak didominasi penggunaan kaca, walaupun jumlahnya relatif sedikit. Wisma Dharmala Sakti Jakarta dan Wisma Dharmala Sakti Surabaya adalah salah satunya. Terlebih, kedua bangunan ini dirancang oleh arsitek asing, yaitu Paul Rudolph. Berdasarkan potensi-potensi yang terdapat pada kedua bangunan, penelitian ini difokuskan pada prinsip Paul Rudolph dalam merancang bangunan perkantoran bertingkat tinggi pada Wisma Dharmala Sakti Jakarta dan Wisma Dharmala Sakti Surabaya.

Melihat fenomena bangunan perkantoran bertingkat tinggi di Indonesia seperti diuraikan sebelumnya, jumlahnya yang sedikit dan artikulasi bentuknya yang variatif membuat bangunan perkantoran bertingkat tinggi rancangan Paul Rudolph di Indonesia menjadi menarik untuk dibahas dan dipahami lebih dalam. Penelitian ini bertujuan untuk mengungkap seluruh hubungan yang terjalin antara prinsip perancangan Paul Rudolph dengan bangunan Wisma Dharmala Sakti Jakarta dan Wisma Dharmala Sakti Surabaya.

Menggunakan metode kualitatif-interpretatif, penelitian ini menggunakan teori terkait pemahaman fungsi perkantoran, serta teori terkait latar belakang dan dasar pemikiran Paul Rudolph, serta teori perancangan menurut Paul Rudolph sebagai studi literatur. Teori Anatomi bangunan digunakan sebagai alat bedah kasus studi, yaitu Wisma Dharmala Sakti Jakarta dan Wisma Dharmala Sakti Surabaya.

Hasil dari penelitian ini adalah enam butir prinsip perancangan bangunan perkantoran bertingkat tinggi menurut Paul Rudolph yaitu pengulangan bentuk elemen bangunan, hubungan antar ruang, kontrol psikologis manusia, rotasi elemen bangunan, pencahayaan pada bangunan, dan citra atau aksen kawasan. Penerapan prinsip Paul Rudolph pada kedua kasus studi dapat dilihat dominasinya pada rotasi dan pengulangan bentuk elemen bangunan. Penerapan kedua prinsip tersebut dapat memenuhi ketiga aspek perancangan Paul Rudolph yaitu aspek bentuk, konteks, dan siklus.

Manfaat dari diselesaikannya penelitian ini adalah untuk menambah pembendaharaan arsitektur mengenai prinsip perancangan perkantoran bertingkat tinggi di Indonesia bagi institusi pendidikan terkait, menjadi bahan pertimbangan dan masukan agar para arsitek dan pemangku kepentingan lebih peka serta kritis dalam merancang bangunan tinggi di Indonesia, menjadi referensi dan bahan studi mengenai prinsip perancangan bangunan perkantoran bertingkat tinggi bagi mahasiswa, akademisi, arsitek, dan masyarakat dengan fokus studi yang bersangkutan, serta menambah wawasan mengenai prinsip perancangan Paul Rudolph khususnya dalam merancangan perkantoran bertingkat tinggi di Indonesia bagi peneliti.
\end{abstract}

Kata-kata kunci: Paul Rudolph, Prinsip Perancangan, Perkantoran, Wisma Dharmala Sakti Jakarta, Wisma Dharmala Sakti Surabaya

\section{PENDAHULUAN}

Perkembangan Perekonomian di Indonesia menyebabkan peningkatan kebutuhan masyarakat akan tempat yang dapat mewadahi kegiatan-kegiatan perekonomian, khususnya perkantoran. Pada saat yang bersamaan, terjadi keterbatasan lahan akibat ketidakseimbangan antara pertambahan penduduk yang terus meningkat dengan lahan yang tetap (tidak bertambah). Keterbatasan lahan yang terutama terjadi di pusat-pusat kota ini kemudian melahirkan perkantoran dalam wujud bangunan bertingkat tinggi (high-rise building) sebagai bentuk efisiensi lahan. 
Mayoritas bangunan perkantoran bertingkat tinggi di Indonesia mengutamakan efisiensi dan efektifitas baik dari segi ruang, waktu, maupun biaya pembangunan. Akibatnya, muncul bentuk-bentuk bangunan perkantoran bertingkat tinggi yang minim artikulasi bentuk dan fasadnya yang didominasi kaca telanjang.

Walaupun bangunan perkantoran bertingkat tinggi yang didominasi penggunaan kaca merupakan hal yang tidak asing lagi, bukan berarti tidak terdapat bangunan perkantoran bertingkat tinggi dengan desain yang berbeda. Terdapat pula bangunan perkantoran bertingkat tinggi yang memiliki artikulasi bentuk serta memiliki fasad yang tidak didominasi penggunaan kaca, walaupun jumlahnya relatif sedikit.

Dari sedikit bangunan perkantoran bertingkat tinggi yang memiliki artikulasi bentuk dan fasad yang tidak didominasi penggunaan kaca, Wisma Dharmala di Jakarta dan di Surabaya memiliki artikulasi bentuk yang lebih variatif. Kasus studi ini menjadi menarik untuk dibahas, terlebih arsitek yang merancang kedua bangunan ini adalah arsitek asing, yaitu Paul Rudolph. Dikutip dari wawancara Paul Rudolph oleh Robert Breugmann tahun 1993, titik berangkat Paul Rudolph dalam merancang Wisma Dharmala adalah karena melihat fenomena bangunan bertingkat tinggi di Indonesia yang fasadnya didominasi kaca. Ia merasa Indonesia memiliki potensi arsitektur yang sangat berkarakter dan unik, sehingga ia ingin merancang bangunan perkantoran bertingkat tinggi di Indonesia yang unik dan khas Indonesia, yang tidak dapat ditemui di negara lain.

Berdasarkan potensi-potensi yang terdapat pada bangunan Wisma Dharmala Sakti Jakarta dan Wisma Dharmala Sakti Surabaya rancangan Paul Rudolph, prinsip perancangan Paul Rudolph dalam merancang bangunan perkantoran bertingkat tinggi di Indonesia menjadi penting dan menarik untuk dipelajari lebih dalam.

Penelitian ini secara umum difokuskan pada prinsip perancangan bangunan perkantoran bertingkat tinggi di Indonesia. Secara spesifik, penelitian ini difokuskan pada prinsip Paul Rudolph dalam merancang bangunan perkantoran bertingkat tinggi pada Wisma Dharmala Sakti Jakarta dan Wisma Dharmala Sakti Surabaya. Tujuan dari penelitian ini adalah mengungkap seluruh hubungan yang terjalin antara prinsip perancangan Paul Rudolph dengan bangunan Wisma Dharmala Sakti Jakarta dan Wisma Dharmala Sakti Surabaya.

\section{KAJIAN TEORI}

Fungsi Perkantoran. Menurut Pusat Bahasa (2011), kantor didefinisikan sebagai balai (gedung, rumah, ruangan) tempat mengurus pekerjaan atau tempat bekerja, sedangkan sewa didefinisikan sebagai kegiatan memakai sesuatu dengan membayar atau membayar karena memakai atau meminjam sesuatu.

Berdasarkan Peraturan Daerah Kotamadya Daerah Tingkat II Bandung No.14 Tahun 1998 tentang Bangunan, bangunan perkantoran adalah bangunan atas bagian dari bangunan yang diperuntukkan untuk pengurusan administrasi atau perdagangan (tetapi bukan toko, gudang, atau pabrik) dan bagian-bagian perkantoran dari bangunan tiap kelas penghuninya dan membutuhkan sistem alarm otomatis.

Menurut Hunt (1993) Kantor sewa adalah suatu bangunan yang mewadahi transaksi bisnis dengan pelayanan secara profesional. Ruangan di dalamnya terdiri dari ruang-ruang dengan fungsi yang sama, yaitu fungsi kantor dengan status pemakai sebagai penyewa atas ruang yang digunakanya. 
Dari definisi-definisi di atas, perkantoran dapat disimpulkan sebagai ruang atau bangunan/gedung yang digunakan sebagai tempat untuk melaksanakan kegiatan bekerja bagi setiap perusahaan atau pemakai, yang pengadaannya dimaksudkan untuk disewakan kepada perusahaan/pemakai. Dengan demikian segala bangunan/ruang yang berfungsi sebagai wadah yang menampung kegiatan pekerja kantor yang dapat digunakan dengan cara membayar, dapat dikatakan sebagai kantor sewa.

Pentingnya aspek efisiensi dalam perancangan kantor memiliki dampak sebagai berikut: (1) perancangan yang efisien dari sisi pembiayaan pembangunan. (2) penataan ruang dalam yang efisien dan memaksimalkan ruang sewa untuk mendapatkan keuntungan. (3) bangunan menjadi efektif karena dapat menyesuaikan dengan fungsi dan kegiatan yang diwadahi sehingga meminimalkan ruang non-fungsional. (4) penataan ruang, jalur sirkulasi, dann fasilitas layanan harus merata agar dapat memenuhi tuntutan seluruh penyewa. (5) perancangan didasarkan pada factor kebutuhan ekonomi melalui analisa keburuhan dan ekonomi konsumen yang akan menjadi sasaran penyewa.

Dari uraian di atas dapat disimpulkan bahwa dalam merancang fungsi perkantoran, aspek efisiensi dan efektifitas ruang, biaya, dan waktu menjadi prioritas utama dalam perancangan. Aspek efisiensi dan efektifitas ini kemudian menghasilkan suatu modularitas dalam perancangan fungsi perkantoran. Penataan ruang yang bersifat open plan juga dapat menjawab fleksibilitas bangunan guna menjawab efisiensi dan efektifitas ruang mengingat penggunaannya hanya bersifat sementara dan kebutuhannya dapat berbeda-beda, tergantung kebutuhan tiap penyewa/penggunanya.

Arsitek Paul Rudolph. Paul Marvin Rudolph atau lebih dikenal sebagai Paul Rudolph lahir di Elkton, Kentucky pada tanggal 23 Oktober 1918. Ketertarikannya pada bangunan sejak usia muda mendorong Paul Rudolph untuk meneruskan studinya di jurusan arsitektur Alabama Polytechnic (sekarang berganti nama menjadi Auburn University). Selanjutnya, Paul Rudolph sempat menempuh studi lanjutannya di Harvard sebelum akhirnya menjadi seorang perwira di Brooklyn Navy Yard selama Perang Dunia II.

Setelah berakhirnya Perang Dunia II, Paul Rudolph kembali ke Harvard di bawah bimbingan Walter Gropius, sang penggagas Bauhaus, dan lulus tahun 1947. Paul Rudolph memulai karirnya di Sarasota, Florida, sesaat setelah lulus dimana ia kemudian menjadi salah satu orang penting di Sarasota School of Architecture. Tahun 1956, Paul Rudolph menjadi dekan dari Yale School of Architecture. Saat itulah ia menemukan gaya khasnya dengan menggunakan beton yang ia tarik dari berbagai sumber termasuk Frank Lloyd Wright dan Le Corbusier ditambah dengan imajinasinya yang luar biasa dalam mengeksplorasi modularitas dan fungsionalitas. Pada pertengahan tahun 1950-an, ia menjadi salah satu arsitek yang paling terkenal dan dicari di Amerika Serikat. Paul Rudolph kemudian meninggalkan Yale pada tahun 1965 untuk berkiprah di New York.

Pada tahun 1965 karirnya mulai menurun, namun meningkat drastis pada awal tahun 1970. Ia mulai mendapat perhatian dari pengembang di negara-negara berkembang di Asia Tenggara dan menerima proyek-proyek skala besar di Singapura, Hongkong, dan Indonesia.

Pada dekade terakhir dalam hidupnya, Paul Rudolph mengeksplorasi pengaplikasian bangunan tradisional dengan gaya modernnya di Asia Tenggara. Paul Rudolph meninggal akibat kanker asbes pada tanggal 8 Agustus 1997 di New York. 
Dasar Pemikiran Paul Rudolph. Pengalaman hidup dan pemikiran-pemikiran Paul Rudolph yang terbentuk semasa hidupnya membentuk sebuah dasar pemikiran yang digunakan Rudolph sebagai dasar filosofi berarsitekturnya. Dasar-dasar pemikiran tersebut kemudian dapat dikelompokkan menjadi gaya perancangan, penataan ruang, konsep kesatuan, dan pandangannya mengenai respon terhadap tapak. Dasar pemikiran Paul Rudolph antara lain:

Gaya Perancangan: Paul Rudolph berada di bawah pengaruh Walter gropius, sehingga di awal masa perancangannya international style menjadi gaya merancangnya yang cukup kuat. Ia kemudian mempelajari bangunan bersejarah yang memiliki kontrol akan cahaya dan ruang antara bidang masif dan rongga dengan cara yang lebih menarik dan mampu menciptakan suasana yang lebih dinamis. Ia juga merasa bangunan seharusnya memiliki ruang-ruang dengan skala manusia, yang mana ia temui pada karya-karya Frank Lloyd Wright. Saat itulah ia memutuskan untuk menggabungkan konsep international style dengan penataan ruang Frank Llyod Wright.

Penataan Ruang: dalam merancang ruang, Paul Rudolph kerap kali membentuk ruang-ruang interior dan eksterior yang saling memiliki hubungan satu sama lain dan menekankan bahwa ruang pada arsitektur harus menarik secara visual. Ia menghasilkan sebuah rancangan sebagai bentuk seni. Pendekatan rancangannya banyak terinspirasi dari Frank Lloyd Wright yang mengutamakan perancangan ruang dalam sehingga hubungan antara ruang dalam dan luar menjadi lebih baik.

Konsep kesatuan: Menurut Paul Rudolph, konsep utama mengenai kesatuan dapat dicapai dengan menggunakan sistem pengulangan yang dirancang khusus untuk setiap proyek. Sistem ini terdiri dari bentuk berulang, detail struktur yang sama, dan usaha untuk memberi komponen yang identik.

Respon Terhadap Tapak: Menurut Paul Rudolph, terdapat dua hal penting dalam desain, yaitu pengendalian cahaya dan ruang interior, serta pengaruh eksterior dengan konteks lingkungan sekitar. Paul Rudolph selalu melihat tapak dimana bangunannya akan didirikan dan bagaimana lingkungan sekitarnya, termasuk kondisi cuaca dan iklimnya. Tempat yang berbeda akan menghasilkan karakter desain yang berbeda karena harus menyesuaikan dengan keadaan lingkungannya.

Teori Perancangan Menurut Paul Rudolph. Dalam salah satu tulisannya yang berjudul Six Determinants of Architectural Form (Rudolph, 1956: 53-58), Paul Rudolph menjabarkan teoriteori perancangannya. Berikut adalah keenam poin dari teori perancangan menurut Paul Rudolph:

a. Hubungan Bangunan dengan Tapak dan Bangunan di Sekitarnya: menurut Paul Rudolph, untuk membuat bangunan yang dapat diakui keberadaannya, bangunan tersebut perlu melebur dengan lingkungan sekitarnya (termasuk dengan bangunan-bangunan yang ada di sekitarnya). Peleburan tersebut dapat dicapai dengan penyesuaian skala proporsi baik fisik bangunannya itu sendiri maupun skala proporsi ruang-ruang yang terbentuk di antara bangunan.

Fungsi Bangunan Sebagai Dasar Pertimbangan Perancangan: dalam merancang sebuah bangunan dengan fungsi tertentu, prinsip perancangan perlu dihasilkan dari kajian aspek fungsi dan tujuan dari bangunan itu sendiri. Paul Rudolph sendiri masih menganut paham bahwa bentuk dihasilkan dari fungsi (form follow function).

Kondisi Lingkungan Sekitar: pengamatan dan analisis terhadap iklim, lansekap, dan kondisi pencahayaan alami perlu dilakukan sebagai bahan pertimbangan dalam merancang suatu bangunan. Hasil dari pengamatan tersebut kemudian harus dapat diterjemahkan sebagai 
solusi rancangan sebanyak-banyaknya. Hal ini ditujukan agar bangunan betul-betul sesuai dengan konteks lingkungannya.

Penggunaan Material yang Sesuai: setiap material memiliki sifat materi atau ciri khasnya masing-masing (properties). Pemilihan material bangunan harus terintegrasi baik secara lingkungan maupun secara fungsi. Penggunaan material yang tepat akan menjamin keberlangsungan dan keberlanjutan bangunan baik secara fisik bangunan maupun fungsi yang ditampung.

Kontrol Psikologis Ruang: kontrol psikologis ruang dapat dicapai melalui bentuk bangunan secara keseluruhan, maupun melalui tiap elemen ruang dan hubungan antar ruangnya. Sedangkan kontrol psikologis manusia terhadap ruang itu sendiri dapat dicapai dengan memperhatikan skala manusia dan proporsi bangunan.

Spirit Bangunan yang Tak Lekang oleh Waktu: poin mengenai waktu ini adalah poin terpenting dari keseluruhan enam poin teori perancangan menurut Paul Rudolph. Spirit waktu inilah yang seharusnya bisa menghasilkan ekspresi arsitektur yang lebih kaya. Tercapainya kelima poin teori sebelumnya dapat mendukung tercapainya poin yang terakhir ini. Spirit waktu berbicara mengenai keberlangsungan dan keberlanjutan sebuah bangunan, baik secara fisik bangunan itu sendiri maupun secara fungsi.

Dari keenam poin teori perancangan menurut Paul Rudolph di atas, dapat dikaji bahwa sejatinya terdapat empat aspek penting yang perlu diperhatikan dalam merancang sebuah bangunan. Keempat aspek tersebut adalah aspek fungsi, aspek bentuk, aspek konteks, dan aspek siklus. Apabila dikelompokkan, maka aspek fungsi terdiri dari poin nomor dua yaitu fungsi bangunan sebagai dasar pertimbangan perancangan (program). Aspek bentuk terdiri dari poin nomor empat dan lima yaitu penggunaan material yang sesuai (material) dan kontrol psikologis ruang (form and space). Aspek konteks terdiri dari poin nomor satu dan tiga yaitu hubungan bangunan dengan tapak dan bangunan di sekitarnya (site context), dan kondisi lingkungan sekitar (environmental context). Sedangkan aspek siklus terdiri dari poin nomor empat dan enam yaitu penggunaan material yang sesuai (material) dan spirit bangunan yang tak lekang oleh waktu (spirit of time).

Kaitan Dasar Pemikiran dan Teori Perancangan Paul Rudolph. Dari dasar pemikiran Paul Rudolph dapat ditarik menjadi dua aspek besar, yaitu bentuk dan konteks. Dimana porsi aspek bentuk lebih besar daripada aspek konteks itu sendiri, hal ini dikarenakan yang menjadi prioritas utama dalam arsitektur bagi seorang Paul Rudolph adalah keindahan visualnya.

Dalam aspek bentuk Paul Rudolph berbicara mengenai kesatuan yang dapat dicapai melalui pengulangan bentuk elemen bangunan, hubungan antar ruang, dan bagaimana skala manusia bisa sangat berpengaruh pada suatu arsitektur. Dalam teori perancangannya, Paul Rudolph merangkum aspek bentuk ini sebagai kontrol psikologis ruang, yang mana dapat dicapai melalui bentuk bangunan secara keseluruhan dan elemen ruang termasuk hubungan antar ruangnya. Selain itu, modularitas yang menjadi tuntutan dalam langgam international style sehingga bangunan dapat diproduksi secara massal tetap mengakar dalam diri Paul Rudolph. Hanya saja, modularitas ini dikembangkan dengan penggunaan bentuk-bentuk geometri. Pada aspek konteks, Paul Rudolph banyak berbicara mengenai bagaimana memaksimalkan cahaya alami ke dalam bangunan dan bagaimana pembayangan berperan pada eksterior bangunan serta bagaimana kaitan bangunan dengan iklim dan lingkungan fisiknya. Pada teori perancangannya, 
Rudolph mempertajam aspek ini dengan mengelompokkan aspek konteks menjadi dua, yaitu konteks secara tapak, dan konteks secara lingkungan yang lebih besar.

Apabila pada dasar pemikirannya Rudolph hanya berbicara mengenai aspek bentuk dan aspek konteks, dalam teori perancangan yang ditulisnya pada six determinants of architectural form (Rudolph, 1956: 53-58), Rudolph mengembangkan dasar pemikirannya. Rudolph tidak lagi hanya berbicara mengenai aspek bentuk dan konteks, namun diperluas dengan aspek fungsi dan juga aspek siklus. Aspek fungsi ini sangat berpengaruh terhadap bentuk bangunan, bahwa fungsi (aktivitas) seharusnya menentukan bentuk bangunannya (wadah). Sedangkan pada aspek fungsi, Rudolph berbicara mengenai spirit bangunan yang tak lekang oleh waktu.

Dari penjabaran dasar pemikiran Paul Rudolph di atas dapat disimpulkan bahwa teori perancangan menurut Paul Rudolph merupakan pengembangan dan intisari dari dasar-dasar pemikirannya. Teori ini adalah teori yang memungkinkan terciptanya arsitektur yang ideal menurut Paul Rudolph sebagaimana dijabarkan dalam tulisannya, six determinants of architectural form (Rudolph, 1956: 53-58).

Teori Anatomi Bangunan. Untuk mengkaji anatomi bangunan kedua kasus studi, digunakan pendekatan Ruang Lingkup Bangunan (Salura, 2015). Dalam bukunya, Arsitektur yang Membodohkan, Salura mengkaji prinsip penataan arsitektur yang ada pada perancangan karya arsitektur.

a. Lingkup Lingkungan Sekitar: Aspek yang dapat dilihat dalam lingkup ini adalah bagaimana penataan tapak terhadap lingkungan serta bagaimana ruang-ruang yang terbentuk akibat adanya objek studi. Selain itu, yang perlu diperhatikan juga dalam lingkup ini adalah bagaimana bangunan/objek studi merespon lingkungannya.

b. Lingkup Tapak: Kesesuaian dalam lingkup tapak mencakup aspek-aspek perancangan tapak, yang terkait dengan aspek akses, orientasi, zonasi, dan penyikapan terhadap lingkungan di luar tapak. Penetapan zonasi dan sirkulasi menjadi penting dalam lingkup ini. Lingkup tapak juga mencakup kaitan antara ruang-ruang pada tapak dan ruang di luar tapak.

c. Lingkup Bentuk: Konsep utama dalam lingkup bentuk adalah mengenai kesesuaian hubungan ruang, pelingkup ruang, dengan elemen-elemen pembentuknya. Elemen pembentuk yang dimaksud disini adalah struktur dan konstruksi bangunan. Ornamen pun berperan dalam lingkup bentuk ini (apabila ada).

d. Lingkup Sosok: Konsep utama dalam lingkup sosok membahas mengenai relasi bangunan dengan konteksnya, dari tingkat terebukaan atau ketertutupan batas antara kegiatan di dalam bangunan dan kegiatan di luar bangunan. Kuantitas dan kualitas batas perlu diperhatikan, yaitu bentuk, sifat (barrier, filter, switch, dan connector), dan jumlah pembatas.

e. Lingkup Siklus: Lingkup siklus membahas mengenai konsep keberlangsungan dan keberlanjutan bangunan dalam sebuah perancangan arsitektur (sustainability).

Setelah melihat fokus penelitian adalah prinsip perancangan Paul Rudolph terhadap bangunan, dan melihat kasus studi yang digunakan, maka ruang lingkup bangunan yang dipakai dalam penelitian ini adalah lingkup lingkungan sekitar, lingkup bentuk, lingkup sosok dan lingkup siklus karena pertimbangan relevansinya terhadap penelitian ini.

\subsection{KASUS STUDI}


Kasus Studi yang digunakan pada penelitian ini adalah bangunan perkantoran bertingkat tinggi karya Paul Rudolph di Indonesia yaitu Wisma Dharmala Sakti Jakarta dan Wisma Dharmala Sakti Surabaya.

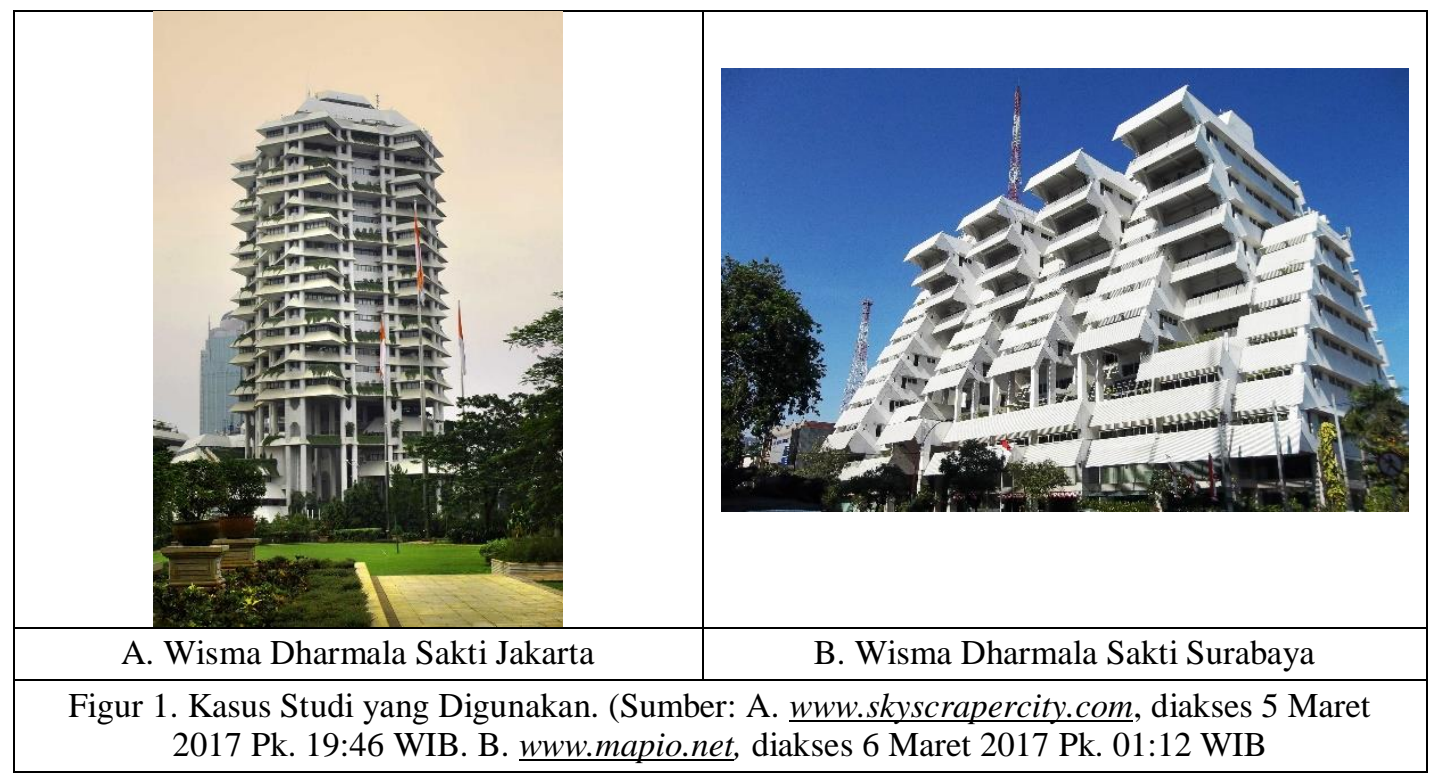

\section{METODA PENELITIAN}

Metode yang digunakan dalam penelitian ini adalah metode kualitatif dengan langkahlangkah: (1) pemilihan kasus studi. (2) melihat dan mengelompokkan fakta. (3) menentukan fokus penelitian. (4) melakukan studi literatur yang berkaitan dengan penelitian. (5) menentukan indikator penelitian berdasarkan hasil studi literatur. (6) survey dan observasi lapangan. (7) mendeskripsikan kasus studi. (8) melakukan analisis. (9) mendapatkan hasil analisis. (10) menyimpulkan penelitian.

\section{ANALISA}

\subsection{PRINSIP PERANCANGAN PAUL RUDOLPH PADA BANGUNAN} PERKANTORAN BERTINGKAT TINGGI

Fungsi Perkantoran Menurut Paul Rudolph. Dalam uraian sebelumnya, disebutkan bahwa dalam perancangan fungsi perkantoran yang menjadi prioritas utama adalah aspek efisiensi dan efektifitas ruang, biaya, dan waktu pembangunan. Hal ini dapat dicapai dengan sistem modularitas dan pengulangan dalam suatu perancangan fungsi perkantoran.

Secara general, pada fungsi perkantoran bertingkat tinggi di Indonesia Paul Rudolph menggunakan bentuk-bentuk geometrik dengan sistem grid yang dikembangkan menggunakan rotasi. Pada Wisma Dharmala Sakti Jakarta, Paul Rudolph memaksimalkan modularitas melalui penggunaan tiga tipe lantai tipikal yang disusun berulang dengan grid diagonal. Sedangkan pada Wisma Dharmala Sakti Surabaya, modularitas hanya dapat terlihat pada grid struktur dan tidak dapat terlihat pada penggunaan lantai tipikal. Sedangkan pengulangan dapat dilihat pada pengulangan elemen bentuk massa bangunan yang disusun secara horizontal. 
Apabila mayoritas melihat efisiensi dan efektifitas bangunan perkantoran pada ruang, biaya, dan waktu pembangunan, Paul Rudolph mempunyai pandangan yang berbeda mengenai efisiensi dan efektifitas bangunan perkantoran. Baginya, yang menjadi penting pada fungsi perkantoran bertingkat tinggi adalah efisiensi dan efektifitas energi.

Hal ini diperkuat dengan hasil wawancara yang menyatakan bahwa bangunan Wisma Dharmala Sakti Jakarta dan Wisma Dharmala Sakti Surabaya kurang efisien secara ruang (dimana data menunjukkan efisiensi bangunan Wisma Dharmala Sakti Jakarta hanya sebesar 65\%). Menurut Bapak Rudy Kuntoaji, Direktur Hospitality dan Manajemen Properti PT. Intiland Development Tbk (pengelola gedung), masih banyak ruang tidak terpakai pada kedua bangunan, khususnya ruang luar yang berupa teras-teras.

Walaupun demikian, secara efisiensi energi, Paul Rudolph dapat dikatakan berhasil. Terasteras besar yang dikatakan tidak efektif digunakan tersebut juga berfungsi sebagai teritis yang memberikan pembayangan pada keseluruhan bangunan. Dengan adanya teritis ini, sinar matahari langsung yang masuk ke dalam bangunan dapat disaring. Hal ini menyebabkan suhu panas tidak terlalu banyak masuk ke dalam bangunan. Dengan demikian, penggunaan penghawaan buatan dapat diminimalisir. Selain itu, penggunaan skylight untuk memasukkan pencahayaan alami juga menyebabkan pencahayaan buatan dapat diminimalisir, terutama pada siang hari. Sesuai dengan tujuan Paul Rudolph merancang bangunan Wisma Dharmala baik di Jakarta maupun di Surabaya dengan teritis-teritis, hasil wawancara dengan pengelola gedung juga menyatakan bahwa kedua bangunan berhasil menghemat penggunaan listrik untuk penghawaan buatan dan pencahayaan buatan sebesar $20 \%$.

Filosofi Perancangan Paul Rudolph. Bagi Paul Rudolph, insting manusia dalam menghadapi alam adalah kemampuan manusia yang terbesar. Inilah yang menjadi alasan mengapa respon terhadap konteks menjadi penting bagi Paul Rudolph. Respon terhadap konteks yang dimaksud oleh Rudolph tidak hanya terbatas pada pemilihan material bangunan saja, tetapi juga pada karakteristik bentuknya.

Bagi Paul Rudolph mengembangkan potensi tapak/kawasan tempat sebuah arsitektur berdiri adalah sesuatu yang sangat esensial. Menurutnya, sudah seharusnya setiap kota, atau kawasan memiliki identitas arsitekturnya sendiri yang unik. Identitas ini dapat dipengaruhi oleh budaya masyarakatnya, material lokal yang ada, dan karakteristik bangunan vernakularnya.

Hal ini diperkuat dengan tulisannya mengenai regionalisme (Paul Rudolph, 2004: 43-45), Paul Rudolph berkata bahwa penghawaan buatan adalah musuh dari regionalisme yang meniadakan pertimbangan iklim. Menurutnya, orientasi bangunan, pembayangan, pertimbangan arah perubahan angin, dan kelembaban merupakan salah satu cara menghadirkan arsitektur yang kontekstual, bahwa mengendalikan udara di dalam ruang secara alami juga sama pentingnya. Pengadaan penghawaan buatan berdampak pada penggunaan energi. Hal ini lah yang sebenarnya diminimalisir oleh Paul Rudolph, bahwa suatu bangunan harus dapat menggunakan kondisi iklim sebagai solusi rancangannya.

Selain filosofinya mengenai respon bangunan terhadap konteks yang sangat kuat, Paul Rudolph juga menyatakan secara tegas bahwa setiap bangunan rancangannya harus menarik secara visual. Hal ini terbukti dengan kedua bangunan rancangannya di Indonesia, Wisma Dharmala di Jakarta dan di Surabaya. Kedua bangunan ini memberikan kesan sculptural layaknya karya seni.

Pada kedua bangunan Wisma Dharmala, kajian fungsi dilakukan di awal, namun pertimbangan fungsi bukanlah prioritas utama dalam merancang kedua bangunan ini. Hal ini dapat 
terlihat dari kedua bangunan Wisma Dharmala yang sangat kaya akan artikulasi bentuk, dimana tiap sudut/elemen bentuk menjalankan fungsi nya masing-masing, tanpa ada yang berperan sebagai ornamen belaka. Dari sanalah dapat disimpulkan bahwa Paul Rudolph adalah seorang arsitek yang bergerak melalui bentuk sebagai prioritas, baru setelah itu fungsi yang menyesuaikan.

Pencahayaan dan Pembayangan Sebagai Respon Terhadap Konteks. Terdapat dua aspek utama dalam usaha Paul Rudolph merespon konteks pada bangunan perkantoran bertingkat tinggi. Kedua aspek ini sama-sama berbicara mengenai penggunaan cahaya dan pembayangan pada bangunan. Paul Rudolph mengatakan bahwa usahanya dalam menghasilkan bangunan yang merespon tapak berbicara mengenai bagaimana memasukkan cahaya alami semaksimal mungkin ke ruang dalam bangunan dan bagaimana cahaya dan pembayangan memberikan eskpresi pada eksterior bangunan.

Dalam memasukkan cahaya ke dalam bangunan, Paul Rudolph membuat banyak bukaan pada kedua bangunan, baik Wisma Dharmala Sakti Jakarta dan Wisma Dharmala Sakti Surabaya. Hampir seluruh pelingkup bangunan berupa bukaan jendela kaca. Selain itu, Paul Rudolph juga membuat void-void dengan skylight sehingga cahaya dapat masuk dan menerangi tidak hanya satu lantai melainkan beberapa lantai sekaligus. Hal ini ditujukan untuk mengurangi penggunaan lampu (pencahayaan buatan) pada siang hari.

Paul Rudolph mempelajari bangunan-bangunan bersejarah yang menurutnya memiliki kontrol akan cahaya. Dari sanalah ia menyadari bahwa permainan gelap-terang dapat membuat banguan rancangannya lebih dinamis dan menarik secara visual.

Kedua bangunan Wisma Dharmala, baik di Jakarta maupun di Surabaya sama-sama memanfaatkan cahaya dan pembayangan sebagai elemen pembentuk fasadnya. Teritis-teritis sekaligus teras pada kedua bangunan menciptakan permainan maju-mundur dan gelap-terang yang dramatis pada fasad bangunan. Kontrol cahaya pada eksterior bangunan ini juga ditujukan untuk menunjukkan skala bangunannya yang manusiawi, dimana pengamat dapat melihat lapisan lantai dengan jelas akibat adanya permainan gelap-terang dan maju-mundur tersebut. Lapisan lantai ini menstimulasi otak pengamat untuk menyesuaikan skala bangunan dengan skala manusia.

Kedua aspek di atas dapat dicapai melalui rotasi elemen bentuk dan pengulangan. Rotasi elemen bangunan dan pengulangan penyusunan elemen bangunan dapat menciptakan teritis-teritis yang berfungsi sebagai pembayangan. Dengan demikian, membuat bukaan besar untuk memasukkan cahaya alami tidak menjadi masalah.

Selain itu, rotasi dan pengulangan bentuk elemen bangunan juga menghasilkan bentuk bangunan yang memiliki artikulasi bentuk yang baik. Artikulasi bentuk inilah yang menentukan permainan gelap-terang yang jatuh pada bangunan dan menciptakan suasana fasad bangunan yang lebih dinamis.

Prinsip Perancangan Bangunan Perkantoran Bertingkat Tinggi Menurut Paul Rudolph. Dalam salah satu tulisannya yang berjudul Six Determinants of Architectural Form (Rudolph, 1956: 53-58), Paul Rudolph menjabarkan teori-teori perancangannya. Seperti telah dijabarkan pada bab sebelumnya bahwa keenam teori perancangan ini dapat disimpulkan menjadi empat aspek yaitu aspek fungsi, aspek bentuk, aspek konteks, dan aspek siklus.

Teori perancangan ini kemudian akan menghasilkan prinsip perancangan yang spesifik dengan fungsinya, yaitu perkantoran bertingkat tinggi. Berdasarkan pembahasan sebelumnya, rancangan Paul Rudolph (termasuk bangunan perkantoran) tidak terikat dengan gaya internasional, 
melainkan dikembangkan dengan menggunakan bentuk-bentuk yang disesuaikan dengan lokasi maupun budaya tempatnya berdiri, karena respon terhadap konteks adalah salah satu nilai penting bagi Paul Rudolph. Selain itu, karena bentuk adalah prioritas utama Paul Rudolph dalam merancang, maka setiap rancangan perkantoran harus memiliki komposisi bentuk massa bangunan yang menarik secara visual dengan memperhatikan efisiensi ruang yang dapat dicapai dengan modularitas dan pengulangan elemen bentuk bangunan. Oleh karena itu, prinsip perancangan Paul Rudolph pada bangunan perkantoran bertingkat tinggi dititikberatkan pada aspek bentuk dan aspek konteks.

Prinsip perancangan bangunan perkantoran bertingkat tinggi ini adalah kajian dari teori perancangan Paul Rudolph ketika digabungkan dengan fungsi perkantoran bertingkat tinggi. Berikut adalah penjabaran lebih lanjut mengenai poin-poin pada aspek bentuk dalam prinsip perancangan Paul Rudolph:

a. Pengulangan Bentuk Elemen Bangunan (repetition): Pengulangan elemen bangunan dapat menghasilkan kesatuan serta keunikan bentuk. Pengulangan dapat dilakukan pada tipe bentuk massa bangunan maupun pengulangan elemen-elemen tampak bangunan.

b. Hubungan Antar Ruang (space): Ruang dalam dirancang open plan untuk memaksimalkan penggunaan ruangan. Pola denah perlu dirancang sedemikian rupa agar ruangan dapat memiliki hubungan antar ruang yang baik dan beragam.

c. Kontrol Psikologis Manusia (scale): Rancangan harus memiliki kontrol psikologi dengan memperhatikan skala manusia dan proporsi bangunan. Hal ini ditujukan untuk menghadirkan bangunan yang nyaman apabila dilihat dari sudut pandang manusia. Proporsi bangunan juga perlu disesuaikan dengan bangunan-bangunan di sekitarnya.

d. Rotasi Elemen Bangunan (rotation): Dalam upaya menghasilkan komposisi bentuk massa yang menarik secara visual, dalam perancangannya Paul Rudolph kerap kali menggunakan pendekatan rotasi. Hal ini ditujukan agar bangunan memiliki artikulasi bentuk yang baik.

Pada aspek konteks yang termuat di dalamnya adalah pencahayaan pada bangunan, dan citra atau aksen kawasan. Berikut adalah penjabaran lebih lanjut mengenai poin-poin pada aspek konteks dalam prinsip perancangan Paul Rudolph:

a. Pencahayaan pada Bangunan (light): Rancangan perkantoran memiliki kontrol terhadap pencahayaan interior bangunan dan pembayangan pada eksterior bangunan. Pembayangan berfungsi untuk mengurangi panas matahari yang masuk ke dalam bangunan dan berfungsi memberi tekstur gelap-terang pada tampak bangunan.

b. Citra atau Aksen Kawasan (context): Kesesuaian dengan konteks dapat dicapai dengan meleburkan bangunan dengan lingkungan dan keadaan sekitarnya. Dengan melihat konteks tempat dan lokasi (termasuk lingkungan) bangunan akan menjadi lebih sesuai dengan alam dan iklim setempat, dan memungkinkan bangunan untuk bertahan lama. Setiap rancangan perlu menggambarkan citra kawasannya, atau menjadi aksen pada kawasannya.

\subsection{PRINSIP PERANCANGAN PAUL RUDOLPH PADA KASUS STUDI}

\subsubsection{ASPEK BENTUK}

Pengulangan Elemen Bentuk. Pada Wisma Dharmala Sakti Jakarta, pengulangan terdapat pada penggunaan bentuk dasar yang berulang (persegi) sehingga membuat ketiga denah tipikal memiliki kesan kesatuan yang kuat. Pengulangan juga terjadi pada penyusunan ketiga tipe lantai tipikal secara berselang-seling. Pengulangan ketiga tipe tipe lantai tipikal berdampak pada pengulangan fasad. 
Pada Wisma Dharmala Sakti Surabaya, pengulangan dilakukan pada kedua tipe bentuk massa bangunan yang kemudian disusun berulang secara selang-seling. Pengulangan penyusunan dilakukan dengan orientasi horizontal. Hal ini menyebabkan bangunan tidak memiliki lantai tipikal

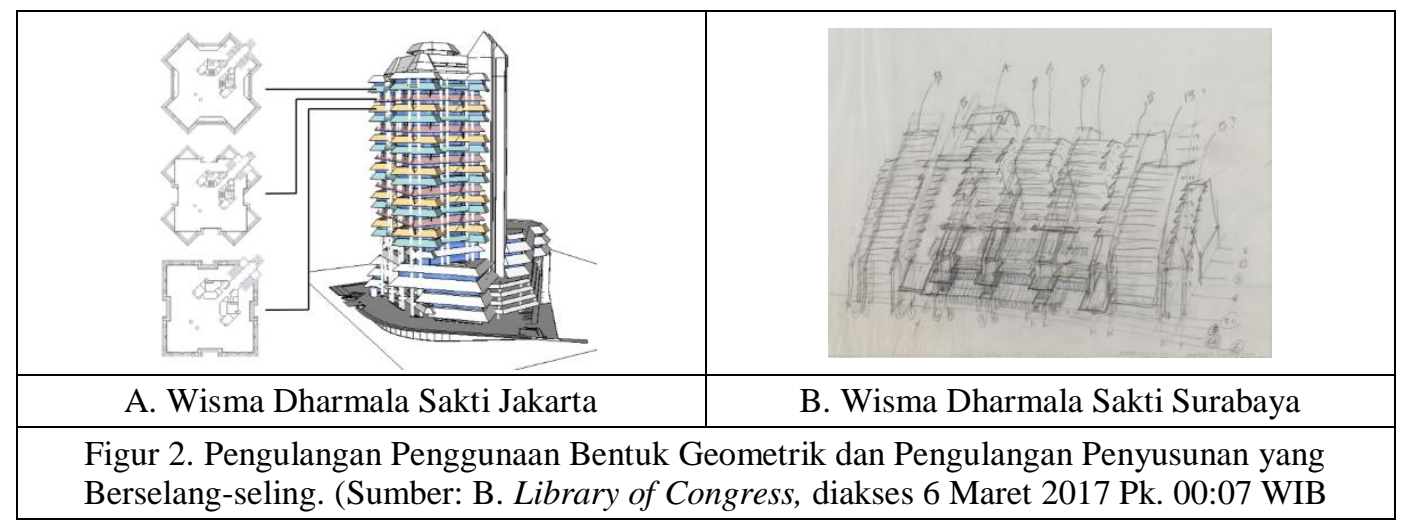

Hubungan Antar Ruang. Pada Wisma Dharmala Sakti Jakarta, ketiga tipe lantai tipikal diracang menggunakan sistem penataan open plan. Hal ini ditujukan agar ruangan memiliki fleksibilitas yang tinggi mengingat fungsinya sebagai kantor sewa. Ruang dalam dan ruang luar dihubungkan dengan penggunaan teras-teras yang sekaligus berfungsi sebagai teritis dan elemen tampak.

Walaupun tidak terdapat lantai tipikal pada Wisma Dharmala Sakti Surabaya, seluruh lantai yang difungsikan sebagai kantor sewa dirancang menggunakan sistem penataan open plan. Ruang dalam dan ruang luar dihubungkan dengan penggunaan teras-teras yang dilengkapi dengan sirip-sirip horizontal yang berfungsi sebagai pembayangan ruang di dalamnya.

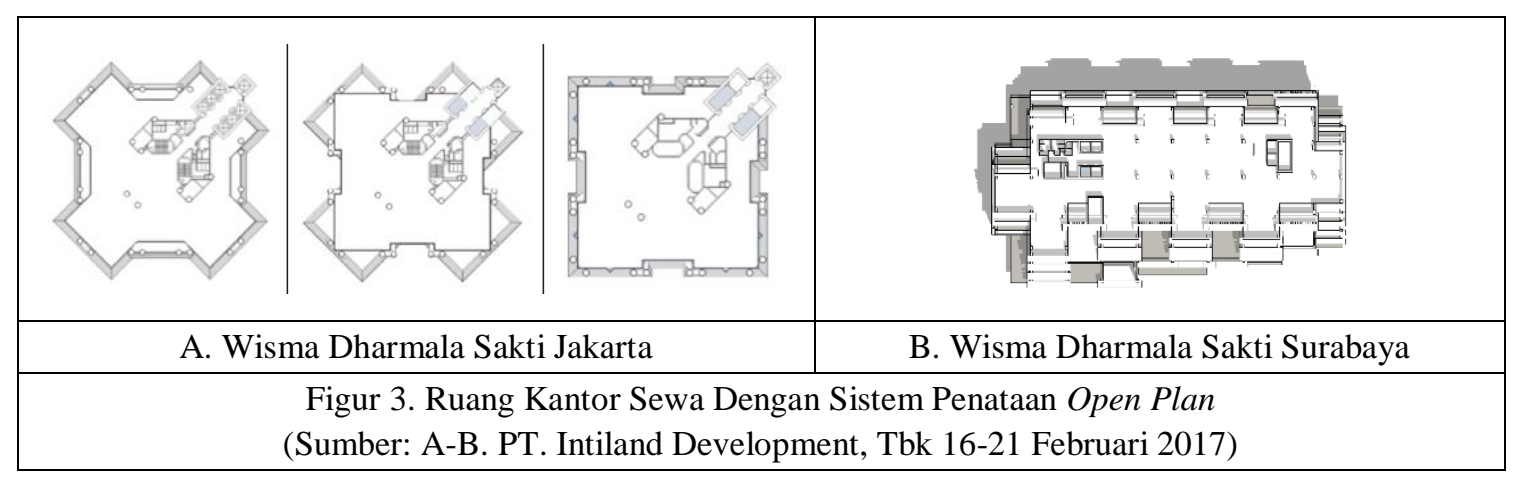

Skala (Kontrol Psikologis Manusia). Pada Wisma Dharmala Sakti Jakarta, kontrol psikologis diterapkan dengan penggunaan teras-teras untuk memperlihatkan lapisan lantai sehingga bangunan tidak terlihat gigantic. Selain itu, teras juga ditujukan untuk memberikan kenyamanan landed-architecture. Pada ruang dalam, skala ruang diatur dengan penyesuaian ketinggian langitlangit berdasarkan aktivitas yang ditampungnya.

Pada Wisma Dharmala Sakti Surabaya, kontrol psikologis diterapkan dengan memperlihatkan lapisan lantai melalui penggunaan teras-teras dan sirip-sirip penangkal sinar matahari yang disebut spandrel. Penggunaan langit-langit disesuaikan dengan aktivitas. Terdapat void besar pada lobby utama untuk memberikan kesan nyaman ketika ruangan dipenuhi pengguna. 


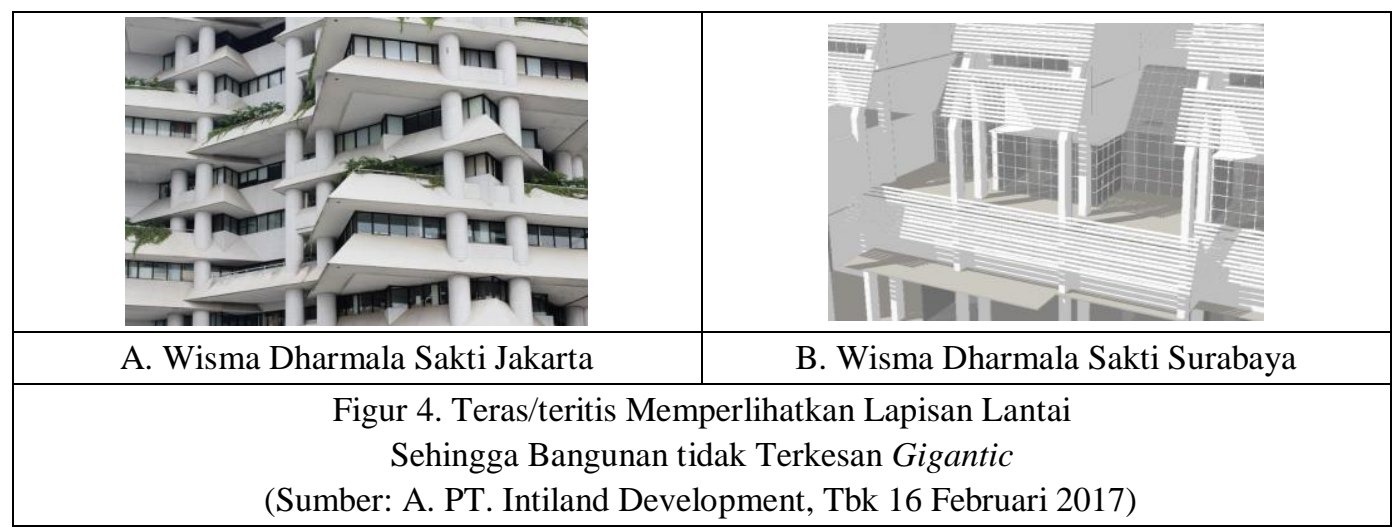

Rotasi. Pada Wisma Dharmala Sakti Jakarta, rotasi dilakukan pada bentuk dasar (persegi) ketiga tipe denah lantai tipikal. Rotasi dilakukan dengan orientasi horizontal. Rotasi ketiga tipe denah inilah yang mempengaruhi bentuk dan fasad bangunan sehingga memiliki artikulasi bentuk yang baik.

Pada Wisma Dharmala Sakti Surabaya, artikulasi bentuk terjadi karena adanya rotasi secara vertical pada massa bangunan yang menggunakan bentuk dasar trapesium sama kaki. Bentuk trapezium yang dirotasi secara vertikal menimbulkan kesan maju-mundur pada bangunan. bentuk trapesium tersebut dikobinasikan dengan bentuk jajargenjang.

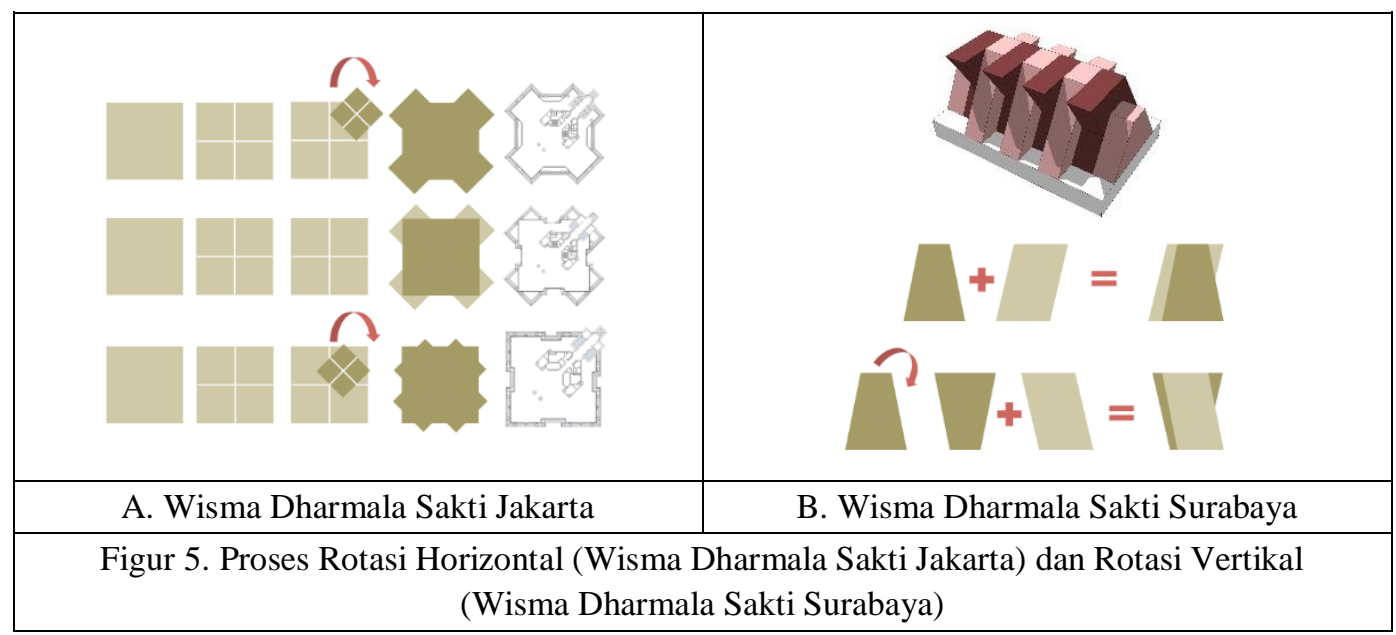

\subsubsection{ASPEK KONTEKS}

Pencahayaan. Pada Wisma Dharmala Sakti Jakarta, untuk memaksimalkan masuknya cahaya matahari ke dalam ruangan, maka dinding-dinding bangunan yang bersinggungan langsung dengan bagian luar bangunan dirancang menggunakan bidang transparan (kaca). Selain itu, penggunaan skylight pada lobby dan griya tawang juga ditujukan untuk memasukkan cahaya alami ke dalam bangunan. Pencahayaan buatan pada Wisma Dharmala Sakti Jakarta selalu dilengkapi dengan lempeng perunggu. Lempeng perunggu ini ditujukan untuk mengurangi rasa silau yang berlebihan, sekaligus memberikan suasana ruang yang lebih hangat (memantulkan warna coklatkeemasan).

Pada Wisma Dharmala Sakti Surabaya, dinding-dinding yang bersinggungan langsung dengan bagian luar bangunan juga dirancang menggunakan kaca untuk memasukkan cahaya alami 
ke dalam bangunan. Perbedaannya adalah bidang-bidang ini memiliki sirip-sirip horizontal penangkal sinar matahari. Bentuk massa yang miring dan berundak sekaligus berperan sebagai pembayangan bagi ruang di dalamnya. Ditemukan hal serupa mengenai pencahayaan buatan pada bangunan ini, yaitu penggunaan lempeng perunggu.

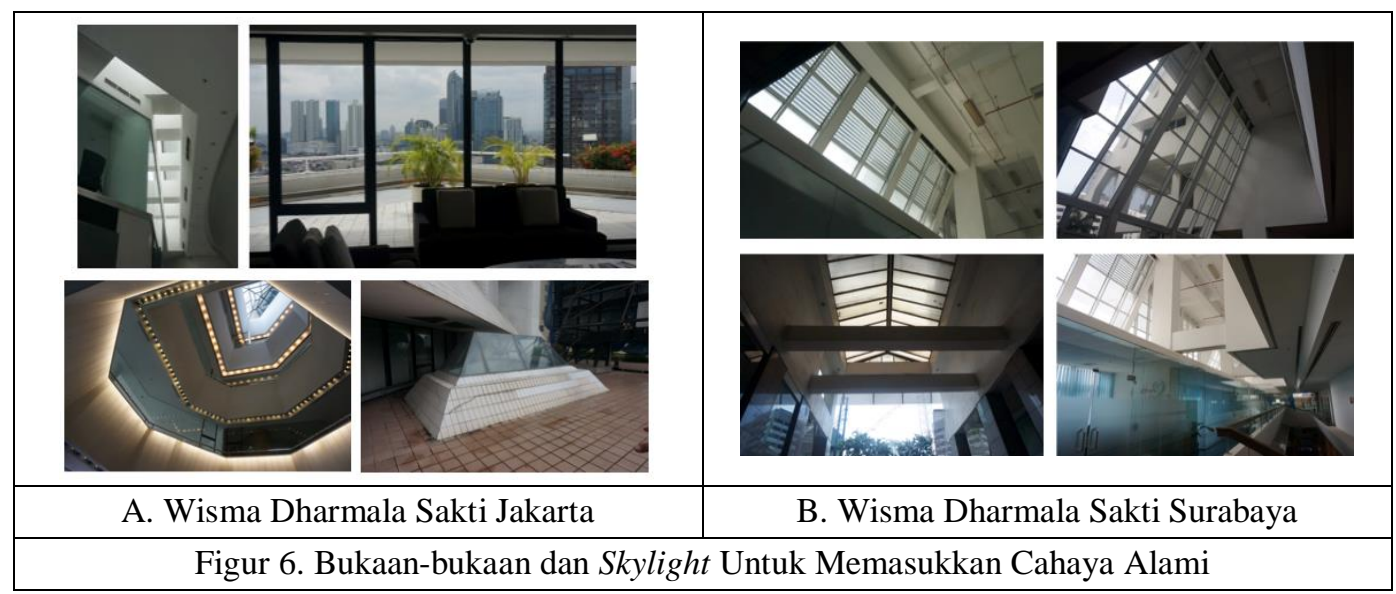

Citra atau Aksen Kawasan. Pada awal masa berdirinya, Wisma Dharmala Sakti Jakarta adalah bangunan bertingkat tinggi yang memiliki ketinggian paling tinggi dibanding dengan bangunanbangunan di sekitarnya yang hanya berkisar 10-12 lantai (Wisa Dharmala memiliki 24 lantai termasuk griya tawang). Bentuk dan ketinggiannya menjadikan Wisma Dharmala Sakti Jakarta sebagai aksen pada kawasan pada saat itu.

Wisma Dharmala Sakti Surabaya dirancang tidak setinggi Wisma Dharmala Sakti Jakarta karena menyesuaikan dengan tinggi bangunan di sekitarnya yang kebanyakan adalah bangunan bertingkat rendah. Dalam hal ini, sebagai fungsi perkantoran Wisma Dharmala Sakti Surabaya kurang efisien karena terbatasnya jumlah lantai yang dapat disewakan.

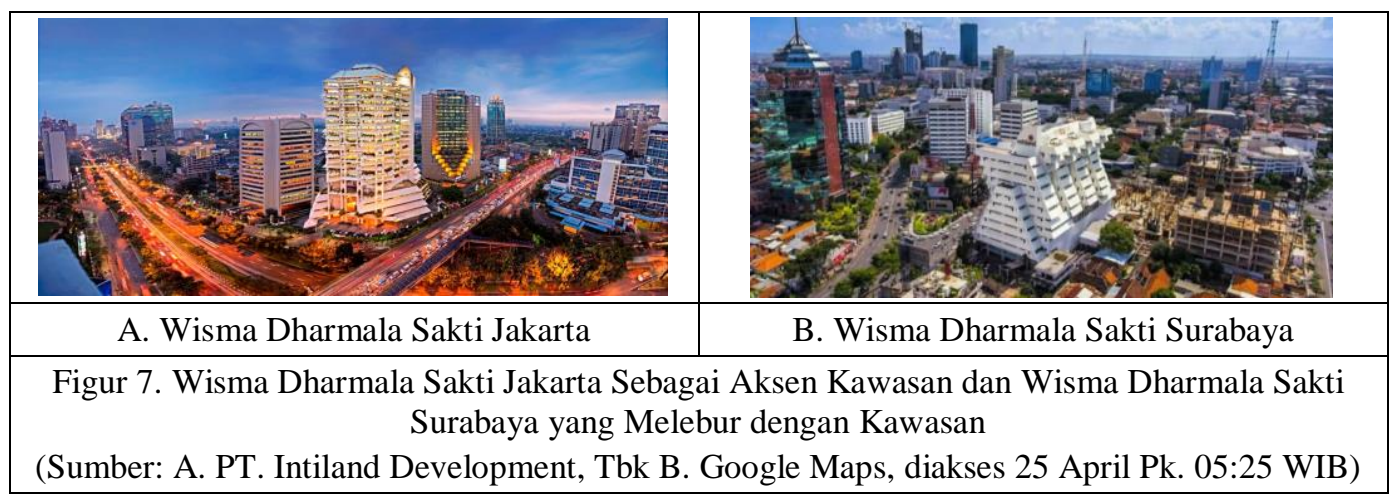

\subsubsection{ASPEK SIKLUS}

Material dan Fisik Bangunan. Pada Wisma Dharmala Sakti Jakarta, seluruh fasad bangunan dilapisi dengan keramik putih. Penggunaan keramik ditujukan untuk memperpanjang umur beton karena melindungi beton dari air sehingga menurunkan potensi tumbuhnya jamur yang dapat merusak/mengurangi kekuatan beton. Untuk membuat bangunan tak lekang oleh waktu, Wisma Dharmala Sakti Jakarta mengadopsi budaya landed-architecture yang ada di Indonesia. 
Hal ini merupakan salah satu usaha yang ditujukan agar bangunan tidak menyebabkan sick building syndrome.

Pada Wisma Dharmala Sakti Surabaya, struktur dan fasad beton tidak dilapisi dengan keramik putih. Untuk membuat bangunan tak lekang oleh waktu, Wisma Dharmala Sakti Surabaya juga mengadopsi budaya landed-architecture. Kenyamanan termal karena adanya teritis/teras dan pembayangan yang baik juga ikut berperan untuk menurunkan potensi terjadinya sick building syndrome pada pengguna bangunan.

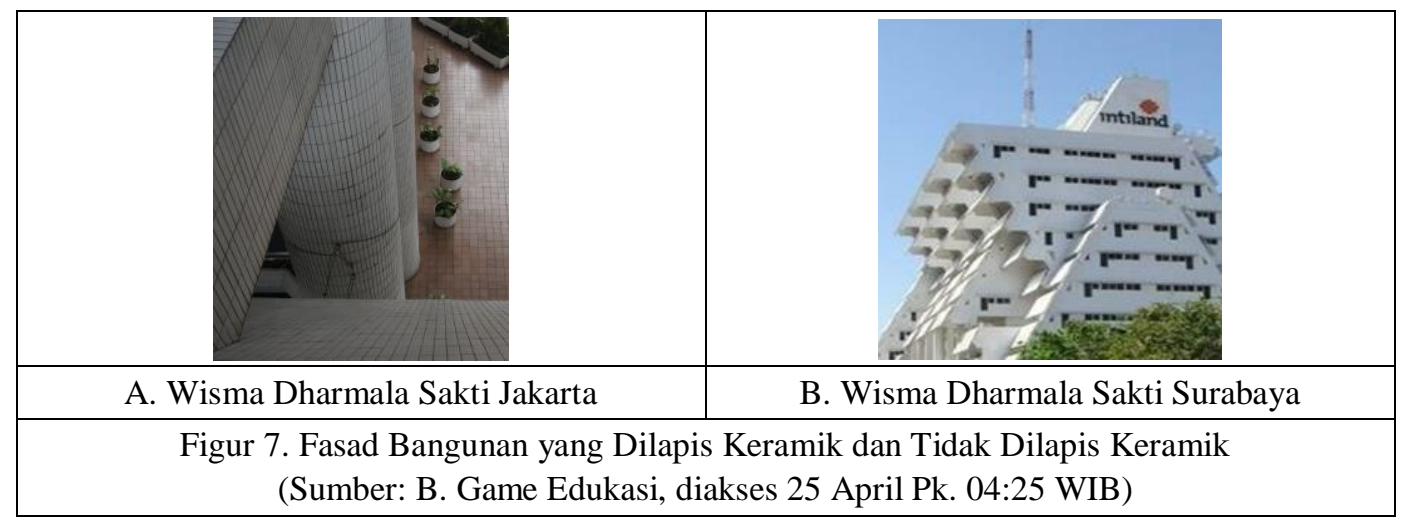

Aktivitas. Wisma Dharmala Sakti Jakarta berada di Jl. Jenderal Sudirman, sedangkan Wisma Dharmala Sakti Surabaya berada di Jl. Panglima Sudirman. Kedua lokasi ini merupakan pusat kota. Kawasan tersebut juga merupakan pusat bisnis dan perekonomian sehingga dipadati dengan bangunan perkantoran lain dan fungsi-fungsi pendukung lainnnya. Hal ini turut berperan dalam menjamin keberlangsungan dan keberlanjutan fungsi yang ditampung.

\section{KESIMPULAN}

Pada latar belakang penelitian, penulis menyatakan dua buah pertanyaan penelitian mengenai bagaimana prinsip Paul Rudolph dan penerapannya pada bangunan perkantoran bertingkat tinggi di Indonesia. Pertanyaan tersebut kemudian menuju kepada sebuah hasil yang ingin dicapai dari penelitian ini. Berikut adalah kesimpulan penelitian yang berupa jawaban atas pertanyaan penelitian tersebut:

\section{Bagaimana Prinsip Paul Rudolph dalam Merancang Bangunan Perkantoran Bertingkat Tinggi?}

Berdasarkan hasil analisis pada bab 4, sistem modularitas dan pengulangan sebagai cara untuk mencapai efisiensi ruang/bentuk, biaya dan waktu pembangunan tetap dipegang erat oleh Paul Rudolph dalam merancang bangunan perkantoran bertingkat tinggi. Namun, sistem modularitas ini dikembangkan dengan menggunakan rotasi sehingga dapat menghasilkan bangunan dengan artikulasi bentuk yang baik.

Namun, bagi Paul Rudolph, efisiensi bangunan perkantoran bertingkat tinggi bukan berada pada ruang, biaya, dan waktu pembangunan, melainkan efisiensi penggunaan energi listrik untuk pencahayaan dan penghawaan buatan yang digunakan pada bangunan. Hal ini dicapai melalui pemanfaatan cahaya alami dan pembayangan. Menurutnya, bangunan yang merespon terhadap tapaknya akan memiliki keberlangsungan dan keberlanjutan yang baik sekaligus memiliki keindahan visual yang baik pula. 
Selain pandangannya yang berbeda mengenai efisiensi bangunan perkantoran, prinsip dasar perancangan bangunan perkantoran tetap diterapkan, salah satunya penggunaan sistem penataan ruang open plan, kesesuaian modul struktur dengan modul ruang, dan efisiensi struktur. Kesesuaian modul struktur dan modul ruang pada Wisma Dharmala Sakti Jakarta kurang diperhatikan karena terdapat beberapa lantai tipikal yang memiliki penataan ruang dengan modul yang tidak sesuai dengan modul struktur sehingga kurang efisien. Wisma Dharmala Sakti Jakarta dapat dikatakan lebih efisien apabila dipandang dari sisi kesesuaian modul struktur dengan modul ruang. Efisiensi struktur dilakukan dengan penggunaan core. Wisma Dharmala Sakti Surabaya memiliki efisiensi struktur yang lebih baik dengan diletakkannya core pada kedua sisi bangunan, sedangkan Wisma Dharmala Sakti Jakarta hanya terdapat pada salah satu sudut bangunan saja dengan pertimbangan efisiensi ruang.

Selain itu, Paul Rudolph juga merasa bahwa respon terhadap konteks (baik konteks secara fisik dan budaya maupun konteks alam/iklim) dimana suatu bangunan berdiri juga merupakan sesuatu yang esensial. Menurutnya, tiap kota atau kawasan harus memiliki identitas arsitekturnya sendiri yang unik. Dalam merespon konteks Indonesia, Paul Rudolph menggunakan pencahayaan alami semaksimal mungkin pada ruang dalam bangunan melalui bukaan-bukaan dan skylight serta menggunakan cahaya dan pembayangan dalam mendefinisikan eksterior bangunan sehingga memiliki kesan yang dinamis.

Kedua cara Paul Rudolph dalam merespon konteks ini dicapai dengan rotasi bentuk dan pengulangan elemen bentuk bangunan. Selain itu, rotasi bentuk dan pengulangan elemen bentuk bangunan ini juga ditujukan untuk menjawab modularitas yang dijunjung pada bangunan perkantoran bertingkat tinggi.

Dari sanalah, dapat ditarik kesimpulan bahwa prinsip perancangan bangunan perkantoran bertingkat tinggi di Indonesia menurut Paul Rudolph yaitu: aspek bentuk yang terdiri dari pengulangan bentuk elemen bangunan (repetition), hubungan antar ruang (space), kontrol psikologis manusia (scale), rotasi elemen bangunan (rotation); dan aspek konteks yang terdiri dari pencahayaan pada bangunan (light) dan citra atau aksen kawasan (context). Selain itu terdapat pula aspek siklus yang diambil dari teori perancangan menurut Paul Rudolph.

Dengan demikian dapat disimpulkan bahwa prinsip perancangan Paul Rudolph pada bangunan perkantoran bertingkat tinggi di Indonesia berjalan sinergis dengan prinsip dan pertimbangan perancangan bangunan perkantoran bertingkat tinggi secara umum.

\section{Bagaimana penerapan prinsip perancangan Paul Rudolph di Wisma Dharmala Sakti Jakarta dan Wisma Dharmala Sakti Surabaya?}

Berdasarkan hasil analisis pada bab 5, pada aspek bentuk: prinsip pengulangan elemen bentuk bangunan dicapai melalui penggunaan bentuk geometrik untuk menciptakan kesatuan bangunan. Yang berbeda pada kedua bangunan adalah orientasi pengulangannya. Pada prinsip hubungan antar ruang, antar ruang dalam diselesaikan dengan sistem penataan ruang secara open plan sedangkan hubungan ruang dalam dengan ruang luar diselesaikan dengan penggunaan teras yang sekaligus berfungsi sebagai terirtis. Prinsip psikologis manusia, pada eksterior bangunan diterapkan dengan memperlihatkan lapisan lantai sehingga bangunan tidak memberikan kesan raksasa, sedangkan pada interior bangunan tinggi langit-langit disesuaikan dengan aktivitas yang ditampungnya. Selain itu, penggunaan teras juga ditujukan agar pengguna bangunan merasa seperti tidak berada di bangunan bertingkat tinggi dan terhindar dari sick building syndrome. Prinsip rotasi elemen bangunan diterapkan dengan menggunakan rotasi sebagai upaya 
mengkomposisikan gubahan massa. Yang berbeda pada kedua bangunan adalah orientasi rotasinya.

Pada aspek konteks: prinsip pencahayaan pada bangunan diterapkan dengan memaksimalkan bidang-bidang trasnparan pada setiap dinding yang berbatasan langsung dengan ruang luar dan adanya skylight. Selain itu setiap pencahayaan buatan dilengkapi dengan lempeng perunggu untuk menciptakan suasana hangat. Pada eksterior bangunan, artikulasi bentuk menciptakan permainan gelap terang yang dinamis. Selain itu, kedua bangunan sama-sama menggunakan warna putih untuk memantulkan panas matahari yang berlebih, hanya saja berbeda materialnya. Dalam mengendalikan pemantulan, digunakan tanaman rampat pada beberapa bagian. Prinsip citra atau aksen kawasan diterapkan dengan gubahan bentuk yang kaya artikulasi dan fasad yang tidak didominasi kaca sehingga kedua bangunan mudah dikenali. Wisma Dharmala Sakti Jakarta dirancang menjadi citra kawasan dengan tinggi bangunan yang lebih tinggi daripada sekitarnya (sekarang sudah tidak seperti itu), sedangkan Wisma Dharmala Sakti Surabaya dirancang menyesuaikan tinggi dengan bangunan-bangunan sekitarnya.

Dengan demikian dapat ditarik kesimpulan bahwa yang menjadi dominan pada prinsip perancangan Paul Rudolph di Indonesia (ditinjau dari kasus studi Wisma Dharmala Sakti Jakarta dan Wisma Dharmala Sakti Surabaya) adalah penggunaan rotasi dan pengulangan. Dengan rotasi dan pengulangan, Paul Rudolph berhasil menjawab seluruh permasalahan rancangan terkait hubungan antar ruang, skala ruang, dan iklim khususnya pencahayaan dan citra/aksen kawasan.

Rotasi dan pengulangan yang digunakan Paul Rudolph pada kedua kasus studi memiliki orientasi yang berbeda. Pada Wisma Dharmala Sakti Jakarta digunakan rotasi horizontal dengan pengulangan vertikal, sedangkan pada Wisma Dharmala Sakti Surabaya digunakan rotasi vertikal dengan pengulangan horizontal. Walaupun berbeda orientasinya, rotasi dan pengulangan ini menciptakan artikulasi bentuk yang baik sehingga dapat merespon terhadap iklim di Indonesia. Hal ini menunjukkan bahwa orientasi rotasi maupun pengulangan tidak berpengaruh pada keberhasilan Paul Rudolph dalam merancang bangunan perkantoran bertingkat tinggi di Indonesia.

\section{DAFTAR PUSAKA}

Breugmann, Robert. 1993. Interview with Paul Rudolph. Chicago: The Art Institute of Chicago de Alba, Roberto. 2003. Paul Rudolph: the Late Work. New York: Princeton Architectural Press

Marlina, Endy. 2008. Panduan Perancangan Bangunan Komersial. Yogyakarta: Andi Publisher. Menzel, Lara. 2009. Architecture \& Design Office. Braun Publishing AG.

Monk, Tony. 1999. The Art and Architecture of Paul Rudolph. United State: Willey Publishing.

Rudolph, Paul Marvin. 1977. 'Enigmas of Architecture' A+U Architecture and Urbanism. Tokyo: A+U Publishing Co, Ltd.

Rudolph, Paul Marvin. 1971. Paul Rudolph, with introduction and notes by Rupert Spade. London: Thames and Hudson.

Rudolph, Paul Marvin. 1970. Architecture of Paul Rudolph. London: Thames and Hudson

Rudolph, Paul Marvin. 1974. The Six Determinants of Architectural Form: Paul Rudolph, 1956. New York: Praeger Publishers

Rudolph, Paul Marvin. 1974. Paul Rudolph: Architectural Drawings. London: Lund Humphries Publishers Ltd.

Rudolph, Paul Marvin. 1957. Perspecta: Regionalism in Architecture. P.12-19.

Salura, Purnama. 2010. Arsitektur yang Membodohkan. Bandung: CSS Publishing

'Remembering Paul Rudolph' di Oculus 60(2). Oktober 1997. Hal. 16-17 
'Interview: Paul Rudolph' artikel oleh Ross Miller. di Progressive Architecture 71. Desember 1990. Hal. 90-92

'Paul Rudolph in Indonesia = Paul Rudolph at Jakarta' di Architettura: Cronache e Storia (36). Juli/Agustus 1990. Hal. 562-564

Peraturan Daerah Kotamadya Daerah Tingkat II Bandung No. 14 Tahun 1998

http://www.paulrudolph.com (diakses 22 januari 2017) 